\title{
An exploratory study of industry 4.0 in Malaysia: a case study of higher education institution in Malaysia
}

\author{
Mohd Arshad Mokhtar, Nurulhuda Noordin \\ Faculty of Computer and Mathematical Sciences, Universiti Teknologi MARA, \\ Shah Alam, Selangor, Malaysia
}

\begin{tabular}{l}
\hline \hline Article Info \\
\hline Article history: \\
Received Jan 10, 2019 \\
Revised Apr 13, 2019 \\
Accepted May 7, 2019
\end{tabular}

\section{Keywords:}

Higher education institution

Human capital

Industry 4.0

Teaching and learning

Work system framework

\begin{abstract}
Industry 4.0 is defining as a smart factory through the emerging technology of the virtual and physical world as a collective term of technologies and concepts of value chain organization. The lack of understanding about Industry 4.0 concepts in Malaysia, especially from Higher Education Institution perspective, becoming an issue in Malaysia. Furthermore, industries in Malaysia are still relying on external expertise to implement Industry 4.0 in their environment with the expectation of an increase in productivity, efficiency, quality and to move away from foreign workers. This research aims to describe the relationship between technologies within Industry 4.0, people and the environment from the perspective of the Higher Education Institution in Malaysia and identify the problem of applying Industry 4.0 at the Higher Education Institution. Qualitative interviews were conducted with participants from an academic area and Industry 4.0 expert who has experience in both industry and academia. The Work System Framework is adopted in this research as a theoretical lens to extract the relevant information and deepen the understanding of applying Industry 4.0 at the Higher Education Institution in Malaysia. Results of this research reveal the problems faced by the Higher Education Institution in Malaysia towards applying Industry 4.0 in teaching and learning based on the relationship of people, technology and the environment. The results may contribute knowledge to the universities in preparation for future-ready graduates or talents as human capital for Industry 4.0 in Malaysia.
\end{abstract}

Copyright () 2019 Institute of Advanced Engineering and Science. All rights reserved.

\section{Corresponding Author:}

Mohd Arshad Mokhtar,

Faculty of Computer and Mathematical Sciences,

Universiti Teknologi MARA,

40450 Shah Alam, Selangor, Malaysia.

Email: myarshad7@gmail.com

\section{INTRODUCTION}

Since the German federal government announced Industry 4.0 as one of the key initiatives of the high technology strategy in 2011, the topic of Industry 4.0 has become popular among industries, research centers, and universities. Many academic publications, practical articles, and conferences have discussed on Industry 4.0 [1]. Malaysia seems like going the same direction as well, where Malaysian federal government is in the process of formulating National Industry 4.0 Blueprint, which expected to be ready by the end of 2017 [2], [3]. Industry 4.0 in Malaysia has been slightly slow to embrace in Malaysia's industries compared to neighbouring countries like Vietnam, Thailand, and Singapore which already have Industry 4.0 policy frameworks [2], [4] and in the adoption phase of Industry 4.0 [5]. According to result survey conducted to Malaysian manufacturers by FMM-Malaysia Institute of Economic Research Business in second-half of 2016, found that only $12 \%$ of respondents are very aware of the Industry 4.0, and that shows Malaysian manufacturers awareness and adoptions of Industry 4.0 were relatively still low [6]. Business leaders in 
Malaysia are showing urgency in embracing Industry 4.0 in their organizations, but the finding of the Microsoft Asia Digital Transformation Survey that most organizations in Malaysia still have minimal digital transformation strategy to embrace Industry 4.0 [7]. These are because many companies lack comprehensive understanding and unfamiliarity on the Industry 4.0 concept [1], [8] and do not want to take a risk as an early adopter to invest in the emerging technologies in Industry 4.0 [9].

Most people in an organization were having problems to grasp the overall idea of technologies in Industry 4.0 to relate to their ecosystem [10], [11]. According to [12] and [13], the Industry 4.0 is best understood as a new level of organization control over the entire value chain of the products life cycle, with the purpose or goal to achieve the higher level of operational efficiency, productivity, and automation [14]. This shows why [15] in their research highlighted the importance of qualified and highly educated person to control Industry 4.0 technologies, but higher education communities in Malaysia were unsure whether they are doing enough to adapt and ready in responding to the Industry 4.0, as shared by [16] during "Redesigning Higher Education Towards Industry 4.0" seminar in Kuala Lumpur. These are leaning toward the issue of lack of understanding, awareness, and readiness about Industry 4.0 in Malaysia, especially at the Higher Education Institution in Malaysia. Which in response to National Policy on Industry 4.0: Industry4WRD launched on 31 October 2018, universities are expected to produce graduates that are well-equipped with relevant and practical Industry 4.0 skills to work in the Industry 4.0 environment in Malaysia and to drive the digital transformation of the manufacturing and related services sector in Malaysia [17].

Preparing talents that need to implement Industry 4.0 is one of the critical challenges and most senior management of organization having difficulty in deciding at which area their workers need to be retrained to suit their new business model toward Industry 4.0 [18], [19]. One of the issues highlighted in the National Policy on Industry 4.0 is a significant shortage of supply for required talents across most of Industry 4.0 technologies such as the Internet of Things, robotics and artificial intelligence [17]. It is crucial to ensure the availability of future talents by preparing students with the necessary competency to work in the Industry 4.0 environment in Malaysia, and that may result in the creation of new or redesign existing university curriculum with multi-disciplinary nature in Higher Education Institution because of the emerging technologies in Industry 4.0 [15]. Even the Russian education system is going for the concept of modernizing to develop students with technical competence, self-sufficiency, independence in judgement, abilities of selfadjustment and communication as the backbone of a professional specialist [20]. Collaboration between universities, accreditation bodies, and industries are important in setting a new curriculum with fundamental core knowledge and social sciences such as leadership ability and creativity, to meet the accreditation criteria [21]. As indicated by [22] and [23], it is essential to have peoples' competencies as the critical asset of the digital business transformation to effectively interact with available technologies in Industry 4.0.

Therefore, this paper presents an exploratory study of Industry 4.0 in Malaysia on a case study of Higher Education Institution in Malaysia. In this research, the interviews are conducted with four participants in an academic area from the selected university. The interview questions are to maneuver them to share their views, opinions, and perceptions based on their roles in the field of teaching and learning at the university regarding Industry 4.0 in Malaysia. The Work System Framework adopted in this research as a theoretical lens to extract the relevant information and deepen the understanding of Industry 4.0 from the perspective of the Higher Education Institution in Malaysia. The results of this research reveal the problems faced by the Higher Education Institution towards applying Industry 4.0 in teaching and learning based on the relationship of people, technologies in Industry 4.0, and the environment. These results were validated by selected Industry 4.0 expert who has experience in both industry and academia. The results may contribute new knowledge to the Higher Education Institution in Malaysia as preparation for future-ready graduates or talents as human capital for embracing Industry 4.0 in Malaysia. The organization of this paper follows by research method, presentation of results and analysis, and finally the conclusion of this research.

\section{RESEARCH METHOD}

The research method for this study is considered as an exploratory in nature and using a qualitative approach. The purpose of this study is to understand, explain, explore, discover and clarify situations, perceptions, values, beliefs, and experience of people and group of people from the selected university about Industry 4.0 at the Higher Education Institution in Malaysia. An exploratory study is "a valuable means of finding out what is happening; to seek new insight; to ask questions and to access the phenomena in a new light" [8]. The research design for this study divided into four phases, which are the introduction, conceptualization, demonstration, and evaluation. Each phase of the research design for this study explained in the next subsection. 


\subsection{Phase I: Introduction Phase}

This first phase consists of two parts. Part A is the introduction of research topic based on literature review analysis from journals, thesis, newspapers and magazine articles that were selected based on a keyword search of Industry 4.0 and Industry 4.0 in Malaysia to identify the existing problem on the research topic. The research question raised from the problem statement is deriving the research objectives within scope and limitation of the research using seven (7) steps of problem formulation of this research [24]. Part B of Phase I are planning and preparation for data collection such as research timeline, interview guide questions and approach, selection of interview participants, choice of tool and framework for data collections and analysis, which will be explained further in the next phases of this research design.

\subsection{Phase II: Conceptualization Phase}

The second phase is where having data collection for this research by interviewed four participants from a private university as listed in Table 1 . The four participants are holding their roles as top management level and middle management level in that private university. The interview session emphasized allowing participants to highlight views, opinions, and perceptions based on their roles in the area of teaching and learning at the university regarding Industry 4.0 in Malaysia.

Table 1. List of Interview Participants for Data Collection

\begin{tabular}{cc}
\hline Participants. & Participants Designation \\
\hline 1 & Deputy Vice Chancellor Academic/Acting Vice Chancellor \\
3 & Senior Lecturer, Faculty of Science and Information Technology \\
4 & Head, Centre of Excellence in Teaching and Learning \\
\hline
\end{tabular}

The nature of qualitative interview for this research has adopted the combination of a semistructured interview and unstructured interview using interview guide questions that derived from the previous phase of this research design, to gain the flexibility during the interview session with participants. According to [25], who emphasized that the qualitative interview to be more like a conversation and participants may be direct in the answers which researchers must be active and listen to the participants in the efforts to understand all, both by direct and indirect input during the interview session. List of interview guide questions was given to participants before the interview sessions, to provide an opportunity to participants for necessary preparation before the interview session. Deliverables of this phase are the transcribed of recorded interview sessions with the participants as data collections that analyzed in the next phase of this research design.

\subsection{Phase III: Demonstration Phase}

In this phase, the transcribed data were analyzed using Thematic Analysis and supported with extended literature reviews. The extended literature review analysis performed in this research for more indepth study from journals, thesis, newspapers, and magazine articles as supporting references for the analysis finding from the perspectives of other authors or researchers related to this research. The Work System Framework as Figure 1 is adopted as a theoretical lens to extract the relevant information and deepen the understanding of this research. In this research, work system is referred to the teaching and learning system in Malaysia's Higher Education Institution to give a proper understanding on how technology, people and environment are inter-related from the perspective of the Higher Education Institution in Malaysia. It is because of the integration of human and machine in performing business processes using available information and technologies to produce desired products and services for internal and external customer in the environment [18], [26].

The trapezoid in grey that surrounding the business processes, participants, information, and technologies in Figure 1 indicates those four elements of Work System Framework constitute the system performing the work. In addition to these four internal elements, the Work System Framework also includes five other elements required for even a cursory understanding a work system. The outputs of a work system are the products and services received by customers. The surrounding environment and the available infrastructure are usually crucial determinants of whether a work system can operate as intended and can accomplish its goals. A work systems' strategy and its relationship to the organization's strategy may or may not be explicit but looking at strategies sometimes help in explaining why a work system operates as it does [26]. Table 2 describes each element of the Work System Framework in Figure 1 that relate to this research as a theoretical lens to extract the relevant information from the data collection for analysis of this research. 


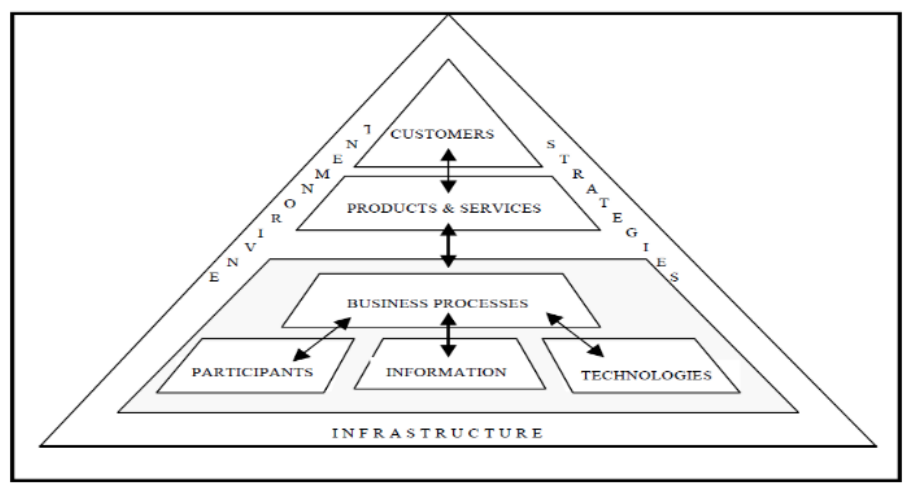

Figure 1. The Work System Framework

Table 2. Descriptions of the Work System Framework Elements

\begin{tabular}{|c|c|}
\hline Elements & Descriptions of the Work System Framework Elements for this research \\
\hline Business Processes & $\begin{array}{l}\text { Business Processes refers work steps through which work is performed within a work system. In this } \\
\text { research, business processes are referred to business processes of university's teaching and learning } \\
\text { toward Industry } 4.0 \text { such as curriculum preparation and implementation. }\end{array}$ \\
\hline Participants & $\begin{array}{l}\text { Work system participants are the people who perform at least some of the work in the business } \\
\text { process. In this research, people refer to lecturers, students and administration people such as } \\
\text { management group. }\end{array}$ \\
\hline Information & $\begin{array}{l}\text { In this research, information is related to the requirement from Industry } 4.0 \text {, which includes } \\
\text { identifying requirement from participants and customers (industry players) to perform the business } \\
\text { processes in those environments. }\end{array}$ \\
\hline Technologies & $\begin{array}{l}\text { Technologies refer to available technologies in Industry } 4.0 \text { such as autonomous robots, simulation, } \\
\text { system integration, Internet of Things, cybersecurity, cloud computing, additive manufacturing, } \\
\text { augmented reality and Big Data that need to be applied or perform or incorporated to the business } \\
\text { processes in the university. }\end{array}$ \\
\hline Product \& Services & $\begin{array}{l}\text { Product and services are the combination of physical things, information, and services that the work } \\
\text { system produces. In this research, product and services are the graduates and internship program that } \\
\text { produces by the work system in the university. }\end{array}$ \\
\hline Customers & $\begin{array}{l}\text { Customers refer to people who receive direct benefit from the product and services of the work } \\
\text { system. Customers often linked to the entire customer experience from determining the requirements } \\
\text { until they acquired the products and services from the work system. In this research, customers } \\
\text { referred to industry players that will receive the graduates (products) and internship program } \\
\text { (services) produced by the business processes in the university. }\end{array}$ \\
\hline Environment & $\begin{array}{l}\text { The environment includes organization, cultural, competitive, technical and regulatory environment } \\
\text { within which the work system operates. Each factor in the environment affect the work system } \\
\text { performance, even though the work system does not directly rely on them to operates, but it still needs } \\
\text { to be considered in the business processes. In this research, the environment referred to industry, } \\
\text { university, government and accreditation body. }\end{array}$ \\
\hline Infrastructure & $\begin{array}{l}\text { Infrastructure includes tangible and intangible that the work system required for operation of the work } \\
\text { system such as human, informational, technical resources and facilities. }\end{array}$ \\
\hline Strategies & $\begin{array}{l}\text { The alignment strategy between work system's strategy and organization's strategy for business } \\
\text { processes and any dependencies with external groups will help in understanding how and why the } \\
\text { work system operates as it does. }\end{array}$ \\
\hline
\end{tabular}

\subsection{Phase IV: Evaluation Phase}

Phase IV is the final phase of this research, where the result of analysis findings for this research was discussed, elaborated and supported by extended literature reviews. The result then validated by an expert from Industry 4.0 domain as shown in Table 3. The nature of qualitative interview for validation to the result of the research finding is still adopting the combination of a semi-structured interview and unstructured interview, to gain the flexibility during the interview session and allowing the expert participant to highlight views, opinions, and perceptions of the result of research findings. Deliverable of this phase is the result of research findings were achieved and validated by the selected Industry 4.0 expert. 
Table 3. The Industry 4.0 Expert Participant Details.

\begin{tabular}{ccc}
\hline Participant & List of Experiences & Total Years of Experiences \\
\hline \multirow{2}{*}{ Expert } & $\begin{array}{c}\text { Committee Member of Malaysia INDUSTRY4WRD, } \\
\text { Senior Lecturer, National TRIZ Innovation Expert, } \\
\text { Engineer and Researcher }\end{array}$ & 16 years \\
\hline
\end{tabular}

\section{RESULTS AND ANALYSIS}

This section discusses the research result of analysis findings on the relationship between technology in Industry 4.0, people and the environment from the perspective of the Higher Education Institution in Malaysia and the problem of applying Industry 4.0 at the Higher Education Institution in Malaysia.

\subsection{The Relationship of Industry 4.0 Technologies, People and Environment}

This research found that all participants shared common views and opinions during the interviews and agreed by the Expert on the research findings as illustrated in Figure 2. Figure 2 shows from the perspective of the Higher Education Institution in Malaysia on the relationship of Industry 4.0 technologies with people in university and environment that involved such as industry, university, and accreditation body. The results reveal that university is aware and realizes to support Industry 4.0 in industry environment by supplying future-ready graduates, the existing teaching and learning curriculum in university need to be enriched and redesigned to have flexibility and option for students to do multi-disciplinary courses such as Bachelor of Information Technology and minor in Finance. As supported by [27] and [28], the creation of better-structured knowledge related to Industry 4.0 is needed by revisiting education contents especially with regards to the technical domain to ensure people are having technical competency readiness for Industry 4.0.

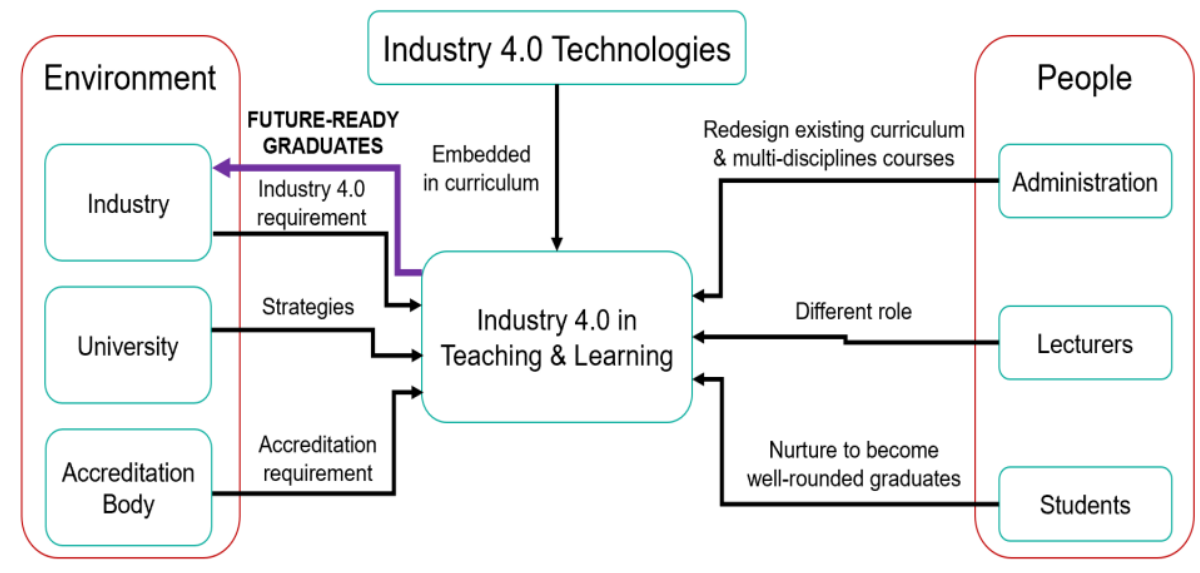

Figure 2. Relationship of Industry 4.0 Technology, People \& Environment (Validated by the Expert)

As shown in Figure 2, all participants highlighted that teaching and learning process requires university as an organization of the Higher Education Institution to strategize teaching and learning curriculum to support Industry 4.0 in Malaysia in the relationship between Industry 4.0 technologies, people and environment as following strategies:

a) Strategy for graduates to become future-ready graduates that is agile with strong technical foundation, generic abilities and ethical values for industry environment that demand on Industry 4.0 capabilities in multi-disciplinary, which combining multiple technologies and subsequently shifting not only "what" and "how" of doing things in economy, business, society and individually, but also "who" we are in the Industry 4.0 era [29].

b) Strategy for teaching and learning to redesign existing curriculum which embedded with Industry 4.0 technologies and multi-disciplines courses without impacting accreditation requirements, as indicated by [30] that modern Higher Education Institution needs to use available data mining tool to assist them to strategize their education plans improvement. As stated in the National Policy on Industry 4.0, it is important to have concrete alignment and collaboration across government, research, academic and industry players regarding industry requirement toward Industry 4.0 [17]. 
c) Strategy for lecturers in changing the role of lecturers as facilitators who facilitate the self-learning by students, so that students can have more knowledge, understanding, exposure to real industry environment and building lifelong learning mindsets, as indicated by [22] and [23] it is essential to have peoples' competencies as critical assets to effectively interact with Industry 4.0 technologies.

d) Strategy for students by nurturing students toward well-rounded graduates with the strong fundamental concept of technical expertise and generic abilities such as complex problem solving, social skills, and ethical values as preparation to the working environment, as reported by [31] and Work Economic Forum's Future of Jobs survey report [29].

\subsection{The Problem of Applying Industry 4.0 at the Higher Education Institution in Malaysia}

However, based on the interviews with all participants, it is not an easy task for a university to apply Industry 4.0 at the Higher Education Institution in Malaysia. Each element in the work system of teaching and learning in the university have difficulties or problems that may impact on the success of applying Industry 4.0 at the Higher Education Institution in Malaysia as shown in red font of the proposed Teaching and Learning Industry 4.0 Model in Figure 3. There are several identified problems of applying Industry 4.0 at Higher Education Institution in Malaysia that need to be managed by university and people that involves such as university administration, lecturers and students such as:

a) Risk of future changes to the Industry 4.0 that made university's management has to take the risk of prediction for strategizing curriculums based on job market and technology trends. As highlighted by [13] and [32], technologies in Industry 4.0 are rapidly changing which give more challenging for the organization to keep up with the necessary skills required to meet new job functions because of technological disruptions that reshape industries for Industry 4.0 implementation. It is essential for the university to ensure students that graduates are relevant to the required skills needed to meet present and future industry demand [28].

b) University's administration is still struggling to find a suitable approach on applying Industry 4.0 technologies in the existing university curriculum, which is similar to the most organization were having the problem to relate Industry 4.0 to their ecosystem [10], [11].

c) University's administration was also struggling in getting approval from the accreditation body for redesigning existing curriculum and multi-disciplines courses, as indicated by [15] it is important for creating new or redesigning existing university curriculum with multi-disciplinary courses because of the emerging technologies in Industry 4.0.

Disruption to the lecturers' roles and expertise when involving multi-disciplines courses, mainly involved with different faculties. As highlighted by [16] that there are few impacts on the teaching method and content by lecturers, the role of students and lecturers, and how will student perform the learning process which causing disruption and resistance toward applying Industry 4.0 in teaching and learning in Higher Education Institution in Malaysia.

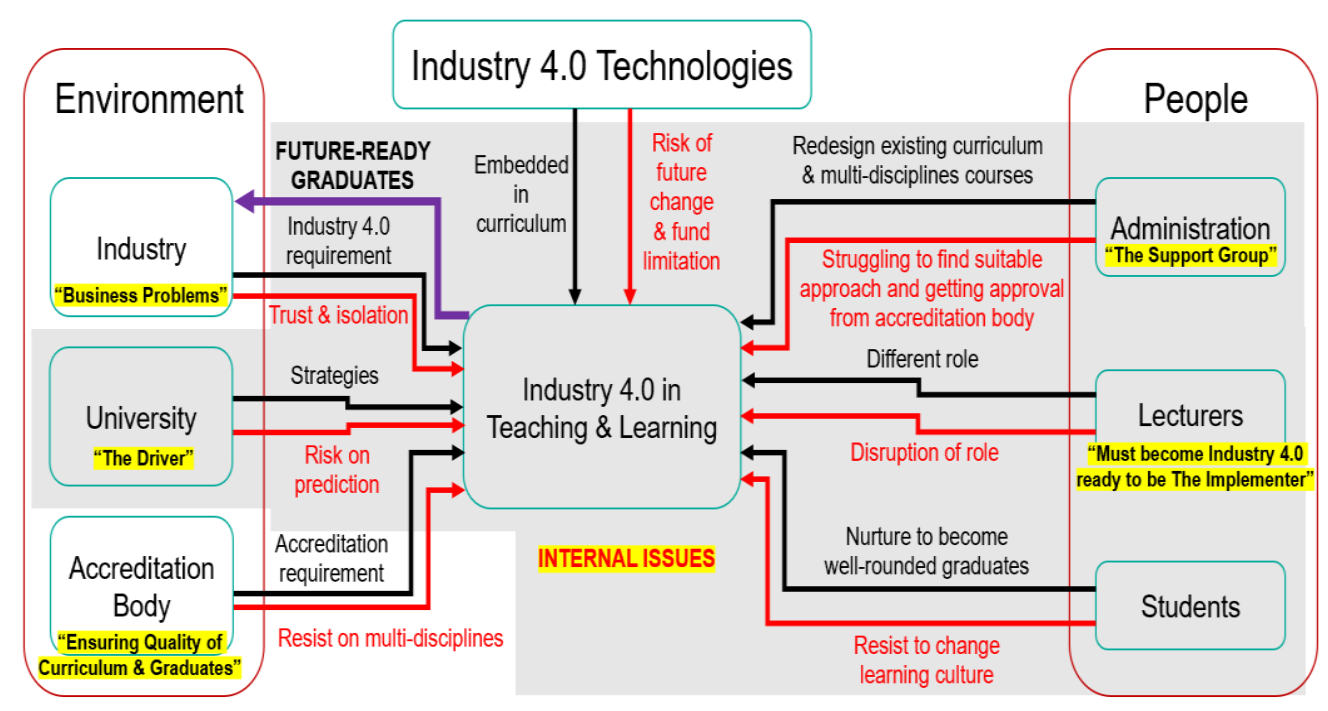

Figure 3. Teaching and Learning Industry 4.0 Model (Validated by the Expert) 
From the interviews, several factors contributed to the identified problems as following:

a) Human behavioral aspect on resistance of disruption, especially students to change their teaching and learning culture from "Chalk and Talk" and "Wait for information is given" to proactively self-learning and developing generic abilities toward seven attributes of well-rounded graduates; technical competency, solution synthesis ability, business acumen, communication \& behavioural skill, practical aptitude, critical thinking and lifetime learning.

b) The resistance of change to the organization's policy and accreditation that is required for a redesign of teaching and learning curriculum to support the Industry 4.0 requirement for graduates with multidisciplines capabilities. As shared by [16], one of the challenges that essential to have agility in governance for higher education accreditation and policy to support applying Industry 4.0 in teaching and learning at the Higher Education Institution in Malaysia.

c) Issues with an insufficient fund to provide the necessary infrastructure in the university environment to apply Industry 4.0 technologies in teaching and learning curriculum as a platform where students can experiment and have exposure on the Industry 4.0 technologies to have better understanding and knowledge while practicing self-learning in university. Which also indicated by [33] in their research that an insufficient fund as one of the challenges faced by the Higher Education Institution in Malaysia. It is essential in the creation of enabling an environment for students and academics to break the barriers, imagination, innovation, and collaboration with multiple disciplines [16].

d) Isolation and trust between industry and university that are expecting the university's curriculum and students readily aligned with industry requirement to implementing Industry 4.0 in their organization. As stated by Participant 1, the university is in cross-junctions of achieving competitiveness against other universities, industry requirement on Industry 4.0 and accreditation requirement. University needs to ensure curriculum offered in the courses for students are within the acceptable duration four to five years because it will incur higher education fees to the students if the proposed courses are more than acceptable duration by includes all technologies in Industry 4.0 to the curriculum.

However, the Expert has several disagreements with the identified problems as marked in the grey background for the red fonts at the Teaching and Learning Industry 4.0 Model in Figure 3. It is because the problems that identified and described are more to internal issues within university instead of industry and accreditation body. He highlighted that "So, what I marked in this finding diagram (refer to Figure 3 ) is all internal, the core is internal. Is it nothing to do with the industry and accreditation body.". He said that the reason is, "Accreditation, the standard that already given such as fundamental knowledge requirement, credit hours to comply in three years, four years and five years, you need to improvise the contents that have elements of Industry 4.0. Then, to design the curriculum again, lecturers must have that knowledge of Industry 4.0". He also said that to successfully applied Industry 4.0 in teaching and learning is by the university itself because they are the key changer or "The Driver" in the university environment. Most participants have shared the problem of the risk on prediction when preparing strategies to apply Industry 4.0 in teaching and learning, which Expert said that, "risk on prediction can manage according to proof and information. The problem on the risk of prediction, not only faced by universities in Malaysia, but also universities in other countries such as at the United States of America, which is the same problem, and the solution to that problem is the same as well. So, it is important to learn from other countries how they solve that problem." As highlighted in National Policy on Industry 4.0, it is essential to pay attention to the enablers and learn from the experiences of other countries in their transformation journey to Industry 4.0 as references for applying Industry 4.0 in Malaysia [17]. As an example, even countries like China and Japan used Germany Industry 4.0 framework as their reference to developing their own national Industry 4.0 strategy framework to make themselves competitive in the market globally [22], [27].

The Expert also disagreed on the people element that the resistance to change the teaching and learning culture is on students. It is because he said that, "It is not students, lecturers who resist. I told you that, there are lecturers in mechanical engineering, if we want to inject Industry 4.0, you need to expose students with projects that have Industry 4.0 elements. But those lecturers are already well-experienced in their engineering field, and so expert and stay in their vertical knowledge, research and expertise, which they do not want to change, they resist...". There are ways to overcome the problem on student resist to change in learning culture to support Industry 4.0, as advised by the Expert, "In teaching and learning, if we want to teach students on Industry 4.0, lecturers have to be Industry 4.0 first. They (lecturers) need to have multidisciplinary readiness, not just silo in mechanical engineering. Three years, five years, 20 years, it not going to happen on multi-disciplinary.". That why it is important for the administration of the university, as highlighted by the Expert, "Administration of the university need to support lecturers to become more exposed to Industry 4.0 and have multi-disciplinary knowledge. So, it has to change in lecturers, only then change the curriculum, and then change the students.". According to the Expert, the lecturers and students will have the exposure to Industry 4.0 by given industry problem-based project, because what industry has is 
business problems, and university need to know and receive a lot of business problem from the industries. The Expert said, "people in the industry have the experience, bring them to the university as lecturers, and it will close the gap.". As indicated by [21, 34, 35], it is important to have collaboration or joint value creation between university and industry whereby, industry players will share industry or business problems, and lecturers can use their research to solve those problems that subsequently creates valuable experience and competencies to the Industry 4.0 teaching and learning at the Higher Education Institution in Malaysia.

\section{CONCLUSION}

This paper presents an exploratory study of Industry 4.0 in Malaysia on a case study of Higher Education Institution in Malaysia. The results of this research based on analysis conducted using Work System Framework as a theoretical lens to extract the relevant information from data collections of interview sessions and extended literature reviews. The results show that Higher Education Institution in Malaysia is aware and realizes that they do have important roles based on the collaborative relationship that needed between Industry 4.0 technologies, people and the environment in strategizing and providing future-ready graduates that are well-rounded in technical competency, generic abilities, and ethical values to support Malaysia toward Industry 4.0 era. Besides that, another result of this qualitative research reveals the problems faced by the Higher Education Institution towards applying Industry 4.0 in teaching and learning at the Higher Education Institution in Malaysia. Several factors contributed to the identified problems that show limitation on knowledge, ability, and exposure on Industry 4.0 that are required for the Higher Education Institution in Malaysia to prepare students for Industry 4.0 environment in Malaysia.

In contrast of this results, interview conducted with Industry 4.0 expert for validation of research findings is pointing that most identified problems highlighted in the research findings are more to internal issues that have its solutions to that problems because these problems not only experienced by Higher Education Institution in Malaysia but other countries as well. As the conclusion, the validated Teaching and Learning Industry 4.0 Model that developed in this research as in Figure 3 that illustrates results of this research may use as new insight or knowledge to benefits Higher Education Institution in Malaysia in preparation of future-ready graduates or talents as human capital. It is essential the future-ready graduates that are agile with strong technical foundation, generic abilities, ethical values and multi-disciplinary capabilities for Industry 4.0 implementation in Malaysia as strategized in National Policy on Industry 4.0. We plan to extend this research to cover public university, industry players and accreditation bodies such as Malaysian Qualifications Agency (MQA) in the vision to have a complete view and expectation toward Higher Education Institution in preparation for future-ready graduates or talents as human capital for embracing Industry 4.0 in Malaysia.

\section{ACKNOWLEDGEMENTS}

We would like to thank the Universiti Teknologi MARA (UiTM), Universiti Teknologi PETRONAS (UTP) and other personnel for supporting this research.

\section{REFERENCES}

[1] Hermann, M., Pentek, T., \& Otto, B., "Design Principles for Industrie 4.0 Scenarios: A Literature Review" Working Paper No. 01/2015, Dortmund: Tehnische Universitat Dortmund and Audi Stiftungslehrstuhl Supply Net Order Management, 2015.

[2] M. Veera, P., "Industry 4.0: The future is here" The Star Online, 6 September 2017. Retrieved from https://www.thestar.com.my/opinion/columnists/along-the-watchtower/2017/09/06/industry-40-the-future-is-heremalaysia-cannot-afford-to-lag-in-a-world-facing-swift-exponential-cha/

[3] Ministry of International Trade and Industry, "Government's Role in Industry 4.0" Industry 4.0 Seminar for Government Officials, 15 June 2017.

[4] Rozana, S., "Riding the Industry 4.0 wave" New Straits Times, 16 August 2017. Retrieved from https://www.nst.com.my/education/2017/08/268377/riding-industry-40-wave

[5] Ming, P., Sikorski, J., Kastner, C. A., Akroyd, J., Mosbach, S., Lau, R., \& Kraft, M. "Applying Industry 4.0 to the Jurong Island Eco-Industrial Park" Energy Procedia, vol. 75, pp. 1536-1541, 2015.

[6] Ee, A. N., "Low awareness, adoption of Industry 4.0 among Malaysian manufacturers" The Sun Daily, 12 October 2017. Retrieved from https://www.thesundaily.my/news/2017/10/12/low-awareness-adoption-industry-40-amongmalaysian-manufacturers

[7] Digital News Asia, "Malaysian Business Leaders Embrace 4th Industrial Revolution" Digital News Asia, 22 June 2017. Retrieved from https://www.digitalnewsasia.com/digital-economy/malaysian-business-leaders-embrace-4thindustrial-revolution 
[8] Montanus, M., "Business Models for Industry 4.0: Developing a framework to determine and assess impacts on business models in the Dutch oil and gas industry" Faculty of Technology, Policy and Management, Delft University of Technology, 2016.

[9] Faller, C., \& Feldmuller, D., "Industry 4.0 Learning Factory for regional SMEs" Procedia CIRP, vol. 32, pp. 88-91, 2015.

[10] Schumacher, A., Erol, S., \& Sihn, W., "A maturity model for assessing Industry 4.0 readiness and maturity of manufacturing enterprises" Procedia CIRP, vol. 52, pp. 161-166, 2016.

[11] Sommer, L., "Industrial Revolution - Industry 4.0: Are German Manufacturing SMEs the First Victims of this Revolution?" Journal of Engineering \& Management, pp. 1512-1532, 2015.

[12] Akeson, L., "Industry 4.0: Cyber-Physical Systems and their impact on Business Models" Master's Thesis, Karlstads University, Karlstad, Sweden, 2016.

[13] Gitarthi, M., "Creating Value with Industry 4.0" Master's Thesis, Massachusetts Institute of Technology, 2016.

[14] Lu, Y., "Industry 4.0: A survey on technologies, applications and open research issues" Journal of Industrial Information Integration, vol. 6, pp. 1-10, 2017.

[15] Benesova, A., \& Tupa, J., "Requirements for Education and Qualification of People in Industry 4.0" Procedia Manufacturing, vol.11, pp. 2195-2202, 2017.

[16] Ali, S., Rose Alinda, A., Syed Norris, H., \& Siti Hamisah, T., "Higher Education 4.0: Current Status and Readiness in Meeting the Fourth Industrial Revolution Challenges" Seminar of Redesigning Higher Education Towards Industry 4.0, Kuala Lumpur, Malaysia, 23-24 August 2017.

[17] Ministry of International Trade and Industry, "Industry 4WRD: National Policy on Industry 4.0" 2018, Retrieved from https://www.miti.gov.my/index.php/pages/view/industry4WRD?mid=559

[18] Bahrin, M. A. K., Othman, M. F., Nor Azli, N. H., \& Talib, M. F., "Industry 4.0: A Review on Industrial Automation and Robotic" Jurnal Teknologi, eISSN 2180-3722, pp. 137-143, 2016.

[19] Schlaepfer, R. C, \& Koch, M., "Industry 4.0 - Challenges and solutions for the digital transformation and use of exponential technologies" Deloitte, Zurich, 2015.

[20] Fatkulina, F., Morozkina, E., \& Suleimanova, A., "Modern Higher Education: Problems and Perspectives" Procedia-Social and Behavioral Sciences, vol. 214, pp. 571-577, 2015.

[21] Nor, N., Rajah, N., \& Ismail, K., "Educating the Engineer of 2020: Malaysian Scenario" Paper presented at the International Conference on Engineering Education (ICEE2008), Budapest, Hungary, 2008.

[22] Correia, M. A., "Industrie 4.0: Framework, Challenges and Perspectives" Master's Thesis, Faculty of Engineering Hochschule RheinMain, University of Applied Science, Germany, 2014.

[23] Motyl, B., Baronio, G., Uberti, S., Speranza, D., \& Fillipi, S., "How will change the future engineers' skills in the Industry 4.0 framework? A questionnaire survey" Procedia Manufacturing, vol. 11, pp. 1501-1509, 2017.

[24] Ranjit, K., "Research Methodology: A step-by-step guide for begineers" SAGE, 3nd. edition, London, 2011.

[25] Ying, R.K., "Qualitative research form start to finish" Guilford Publications, 2nd edition, New York, USA, 2015.

[26] Alter. S., "The Work System Method for Understanding Information Systems and Information System Research" Communications of the Association for Information Systems, vol. 9, pp. 90-104, 2002.

[27] Hecklau, F., Galeitzke, M., Flachs, S., \& Kohl, H., "Holistic approach for human resource management in Industry 4.0" Procedia CIRP, vol. 54, pp. 1-6, 2016.

[28] Angolla, J. E., "Human Capital in the Smart Manufacturing and Industry 4.0 Revolution" In Digital Transformation in Smart Manufacturing, InTech, doi.org/10.5772/intechopen.73575, 2018

[29] Schwab, K., "The Fourth Industrial Revolution" Penguin Random House UK, 2017.

[30] Hussain S., Dahan N.A., Ba-Alwib F. M., and Ribata N. "Educational data mining and analysis of students' academic performance using WEKA" Indonesian Journal of Electrical Engineering and Computer Science, vol 9(2), pp. 447-459, 2018.

[31] Adnan, Y. M., Daud, M. N., Alias, A., \& Razali, M. N., "Importance of Soft Skills for Graduates in the Real Estate Programmes in Malaysia” Journal of Surveying, Construction \& Property vol. 3(2), pp. 1-13, 2012.

[32] Hamiz, M., Bakri, M., Kamaruddin, N., \& Mohamed, A., "Assessment Analytic Theoretical Framework Based on Learners' Continuous Learning Improvement" Indonesian Journal of Electrical Engineering and Computer Science, 11(2), pp. 682-687, 2018.

[33] Ghasemy, M., Hussin, S., Daud, M.A., Nor, M. M., Ghavifekr, S., \& Kenayathulla, H.B., "Issues in Malaysia Higher Education: A Quantitative Representation of the Top Five Priorities, Values, Challenges and Solutions From the Viewpoints of Academic Leaders" SAGE Open, pp. 1-15, 2018.

[34] Paulus-Rohmer, D., Schatton, H., \& Bauernhansl, T., "Ecosystems, strategy and business models in the age of digitization - How manufacturing industry is going to change its logic" Procedia CIRP, vol. 57, pp. 8-13, 2016.

[35] Erol, S., Jager, A., Hold, P., Ott, K., \& Sihn, W., "Tangible Industry 4.0: A Senario-Based Approach to Learning for the Future of Production" Procedia CIRP vol. 54, pp. 13-18, 2016 


\section{BIOGRAPHIES OF AUTHORS}

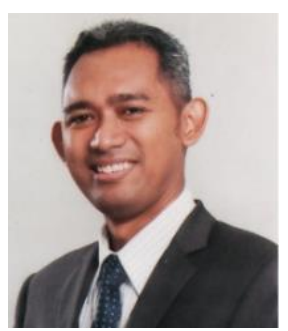

Mohd Arshad Mokhtar is a Master of Science in Information Technology graduates from Faculty of Computer and Mathematical Sciences, Universiti Teknologi MARA, Malaysia and currently worked in PETRONAS ICT Sdn Bhd under Enterprise Architecture, Strategy and Governance division. He has strong interest in the area of Industry 4.0 domain from the conceptual towards the applications of Industry 4.0 technologies in education. businesses and industries environment.

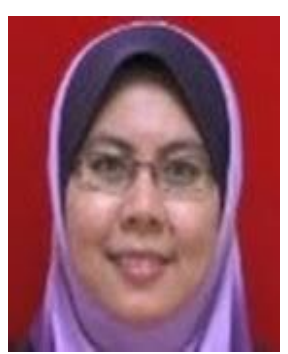

Nurulhuda Noordin is a Senior Lecturer from the Centre of Information Technology Studies, Faculty of Computer and Mathematical Sciences, Universiti Teknologi MARA Shah Alam. Her research interest includes Halal Certification Systems, strategic IT, Human Computer Informatics, E-commerce and IR4.0. Currently, she is a Coordinator Servicing for Computer Sciences at Faculty of Computer and Mathematical Sciences, Universiti Teknologi MARA Shah Alam. 